\title{
Rudolf Stolzmann’s Philosophy of Economics
}

\author{
Lechner Gerhard \\ University of Applied Sciences
}

\begin{abstract}
This paper deals with an economist and philosopher, who is not very well known in the literature, namely Rudolf Stolzmann. Stolzmann considered himself a representative of Neo-Kantianism and in economics he is often ascribed to the social law movement of economics. The research question in this paper deals with the late works of Stolzmann, namely, "Nature and Goals of the Philosophy of Economics.” In this work, Stolzmann made use of another methodology compared to his earlier texts in which society or a sense of community is deducted from a philosophical perspective. This paper aims to show the contradictions of this deductive method. This new approach is no longer compatible with Neo-Kantian philosophy and can be associated more closely with Hegelian or Neoplatonic philosophy; which Stolzmann appears to be unaware of. Conversely, his social organic theory gains greater plausibility and credence than before. Another result of the paper can be seen in the fact that Stolzmann did not use the deductive method consistently. Beginning from the fourth chapter, it gets confusing and Stolzmann mixed the deductive method with the inductive method.
\end{abstract}

Keywords: Neo-Kantianism, Neoplatonic philosophy, philosophy of economics, Rudolf Stolzmann, Hegel, Hermetic philosophy

\section{Introduction}

Rudolf Stolzmann is still not very well known in the economic and philosophic literature. He lived from 1852-1930. Nowadays, there are hardly any essays about Stolzmann. One exception is the essay of Lechner (2016) which deals with the influence of Stolzmann on Schumpeter's interest theory. The most important secondary literature on Stolzmann came from Esser (1971), who wrote a dissertation about the value theory of Böhm-Bawerk and Stolzmann. The basis for the dissertation was a controversy between Böhm-Bawerk and Stolzmann on the value theory in economics. The debate between Böhm-Bawerk and Stolzmann can be found in Böhm-Bawerk's famous essay "Power or Economic law" (1924) ${ }^{1}$ and in Stolzmann's "Basics of a Philosophy of Economics" (1925a). ${ }^{2}$ Esser referred to the interesting fact that the debate between Stolzmann and Böhm-Bawerk was not part of a scientific debate in the existing literature. Lechner (2016) mentioned that Schumpeter was at least partly influenced by Stolzmann. Schumpeter referred to Stolzmann in "The Theory of Economic Development" (Schumpeter 2006, 16) ${ }^{3}$ and in his essay "On the Concept of Social Value" (Schumpeter 1908). The question is now, why was Stolzmann important for famous economists like Schumpeter and Böhm-Bawerk? Stolzmann criticized their value theory. The basis for his own value theory was the fact that economics is always dependent on the definitive legal relationships of the respective time.

Lechner Gerhard, Ph.D., lecturer, FH JOANNEUM, Department of Management, Institute of Banking and Insurance, University of Applied Sciences, Austria; main research fields: International Financial Markets, Monetary Policy, Ethical Banking, Philosophy and Economics, Neoplatonism and Hermeticism. 
Therefore, the value of a good cannot be explained as a natural law as Böhm-Bawerk thought. According to Stolzmann, the legal relationship and the power relationships have to be integrated in the value theory.

The works of Stolzmann are not very well known and therefore a short review of his works appears to be necessary. Stolzmann wrote three books and numerous papers in journals. His first book was edited in 1896 and was called The Social Category in Economics (Die soziale Kategorie in der Volkswirtschaft). The books of Stolzmann have not been translated into English. Stolzmann wanted to integrate the social category in economic theory, because the social category had been considered only in economic policy. What is the social category? For Stolzmann, the world economy can be considered as an organism. ${ }^{4}$ The social categories are the social relationships and the judicial system in a society and in an economy. The term social category was first mentioned by Rodbertus and Adolph Wagner (Böhm-Bawerk 1924, 231). He differentiates between social, natural, and historical category. Natural category means the natural laws and natural conditions (for example the supply of commodities) which are relevant for any economy. Furthermore, Stolzmann assumes a historical category which refers to judicial system changes over time (Stolzmann 1896, 5-9). The second book by Stolzmann was The Purpose in the Economy (Der Zweck in der Volkswirtschaft). This book deals with the social organic and ethical method in economics and is a critique of the Austrian marginal utility theory.

The philosophical method used in this book is an inductive method and the credo "Back to Kant" became very important (Stolzmann 1909, 4). Stolzmann follows the Neo-Kantian philosophy of his time. Especially, Rudolf Stammler, Paul Natorp, and Heinrich Rickert are references (Stolzmann 1909, III-IV). From a social philosophic point of view, Stammler was a scholar of Friedrich Albert Lange, who could be thought of as a forerunner of the Maribor Neo-Kantianist school. Heinrich Rickert was part of the south-west German Neo-Kantianism movement together with Wilhelm Windelband (Pascher 1997). Many arguments which Stolzmann used in his second book go back to the social philosophy of Lange (Lange 1910). From an economic point of view, Stolzmann was regarded as a representative of the social law movement in economics. The main representatives of that school were Rudolf Stammler, Karl Diehl, and Stolzmann (Rieter 2014; Stavenhagen 1964; Diehl 1941). However, Diehl only partly added Stolzmann to the social law movement of economics, because Stolzmann tried to synthesize the social law movement with the Austrian marginalist school (Diehl 1941, 83-84). For Rieter (2014), the social law movement was one movement of the historical school of economics. Strongly related to the social law movement are the social ontological direction which was represented by Gottl-Ottlilienfeld and the holistic direction represented by Othmar Spann. The latter was a prominent philosopher and economist. Spann incorporated the theory of social organism in his philosophy and he influenced the fascist Austrian corporative state from 1934-1938 (Schöpfer 2008). Stolzmann criticized Spann's theory of social organism as a materialistic philosophy and he did not agree with the ideas of a corporate state (Stolzmann 1927). Stolzmann wanted to implement a theoretical social economic theory and there are absolutely no undemocratic ideas in his writings. The third book by Stolzmann was called Basics of $a$ Philosophy of Economics (Grundzügeeiner Philosophie der Volkswirtschaft) and was edited in 1923. This book included a paper called "Nature and Goals of a Philosophy of Economics" (Wesen und Ziele der Wirtschaftsphilosophie). In this paper, Stolzmann wanted to change his method towards the direction of a deductive approach. In the preface of this paper, Stolzmann describes why he changed his method because he wanted to move towards a philosophical unity. Stolzmann makes clear that this deductive method is not consistent with the Kantian and Neo-Kantian method (Stolzmann 1925b, 5-8). 
This paper aims to show the contradictions of the deductive and the inductive approach of Stolzmann. Stolzmann was probably not aware of the strong discrepancies between these methods. On the other hand, his social organic theory became more plausible than it had been before. Another result can be seen in the fact that Stolzmann used the deductive method inconsistently. The paper aims to show these inconsistent accomplishments.

\section{The Basic Principle of Stolzmann's Philosophy of Economics}

This chapter aims to find the principles of the philosophy of economics of the deductive approach of Stolzmann. Stolzmann already changed his methodological view a little bit in "Basics of a Philosophy of Economics.” The philosophical background was more a combination of Neoplatonic, Hermetic philosophy, and Hegel. Stolzmann's "Basics of a Philosophy of Economics" contains a deductive thesis: "Philosophy is the supreme discipline and all other sciences go back to philosophy." Stolzmann represents the hermetic microcosm-macrocosm theory of the Renaissance philosophers Marsilino Ficino, Pico della Mirandola, Agrippa von Nettesheim, and Giordano Bruno. The human being is a microcosm which contains the whole macrocosm. Stolzmann quotes the monadology of Leibnitz which also represented Neoplatonic and Hermetic contents (Stolzmann 1925a). The microcosm-macrocosm relationship is already part of the writings of Hermes Trismegistos and was recovered by the Renaissance Neoplatonists (Ebeling 2005, 172). The influence of Hermes Trismegistos on the Renaissance can be found in many works (for example: Yates 1964; Ebeling 2005). Hermetic philosophy also comprises the method of analogy. Stolzmann used this method particularly in "Nature and Goals of the Philosophy of Economics" (Stolzmann 1925b). Besides, the macrocosm-microcosm analogy Stolzmann created another term called mesocosm. The mesocosm lies between the macrocosm and the microcosm and could be regarded as the "soul or the awareness of the society." Stolzmann assumes a neoplatonic top-down approach, where themacrocosm is "above" mesocosm and microcosm. The society (mesocosm) receives light from "above” (macrocosm) (Stolzmann 1925b, 17-19). The light from above can be interpreted as a reference to the analogy of Plato's sun (Stolzmann 1925b, 23).

The fact that the mesocosm is "above" the microcosm in the philosophy of Stolzmann can be regarded as the basis for his economic theory. Individuals must be considered as an organic part of the society. Without a society, an individual could not exist and without a society, there would be no history and no culture. Other organic parts of a society or the economy are enterprises. However, the analogy does not go into further detail, because Stolzmann merely "plays a little bit with the idea of the analogy" (Stolzmann 1925b, 18). This philosophy contradicts the atomistic and individualistic approach of the Austrian school. Carl Menger, Böhm-Bawerk, and Schumpeter neglected the importance of the society (mesocosm) for the individual being.

To understand the concept of the mesocosm, it is necessary to show the influence of Hegel on Stolzmann. The objective spirit can be interpreted as the mesocosm in the sense of Stolzmann. The essence of the Hegelian objective spirit is manifested in the culture and in the judicial system of a society. Stolzmann often refers to Hegel, but as a Neo-Kantian philosopher, he never fully accepted Hegel's idealism. However, there are studies which show the influence of the Hegelian philosophy on Neo-Kantianism (Krijnen 2007; Zeidler 2002). There is a further important philosopher, namely Plato, who strongly influenced Neo-Kantian philosophy (Holzhey 1997). The influence of Plato on Stolzmann was already demonstrated with the example of the analogy of the sun. However, Plato and Hegel always contradicted the subjective approach of Kant. One example was Paul Natorp, a representative of the Maribor school of Neo-Kantianism. He interpreted Plato's agathon as a 
transcendental philosophical assumption (Natorp 1903). Stolzmann had one problem with the inductive approach in his philosophy of economics. The inductive Kantian philosophy was subjective. Kant indicated in his "Critique of Pure Reason" that a deduction from transcendental ideas (god, immortality, liberty) is not possible (Kant 1906, 344-6). That means a microcosm-macrocosm analogy cannot be deviated with the Kantian methods. Stolzmann changed to a deductive method, because the deviation of the importance of the society for the individual being was much easier.

\section{Matter and Form in Stolzmann's Philosophy}

The fourth chapter of Stolzmann's “Essence and Goals of the Philosophy of Economics” deals with matter and form. Stolzmann partly abandoned the deductive method in this chapter. He mainly refers to the works of Rickert (1928; 1929). Rickert started his considerations from the individual subject and not from god or a macrocosm. Form is not directly compatible with the neoplatonic term soul or the Hermetic microcosm. However, the form neither comes into being nor does it pass away. Matter depends on a development, which means that it comes into being and passes away. Matter and form can be identified with the social and natural category. Form correlates with the social category and matters with the natural category. Social category means a society or the development of a society. One could also call it social awareness (Stolzmann 1925b, 22-28). However, Stolzmann does not define a correlation between social category and mesocosm, which would be logical. Matter is the substance of the economy or the society. Stolzmann concludes that each economy has two constitutional moments, namely, the social and the natural categories. He indirectly refers to the historical category, because there is always generation and corruption in every economy (Stolzmann 1925b, 29).

There are now two different possibilities to analyze economics. First, pure economics beginning with the individual that has a very mechanical or naturalistic philosophy. Stolzmann argued the pure economists got stranded in the matter; they do not reach the form. Stolzmann classified the Austrian school of economics along with the pure economists. The Marxian economists also belong to the naturalistic philosophers. Second, the economy can be considered from a holistic point of view. In this case form is considered to be "above" matter, which means that form creates matter and not vice versa (Stolzmann 1925b, 29). The social law movement of economics could be considered as one example of a holistic approach.

\section{The Value Theory}

At the beginning of the 20th century, value and interest theory was one of the most discussed topics in economics. The neoclassical marginal utility theory became the increasingly dominant explanation of the value of a good. Famous representatives of that theory were Carl Menger, Eugen von Böhm-Bawerk, Friedrich von Wieser, Alfred Marshall, and William Stanley Jevons. Stolzmann discussed his value theory in many works. He criticized the classical, the neoclassical, and the Marxian value theory in his first book Social Categories in Economics (Stolzman 1896), and in his second book The Purpose in the Economy (Stolzmann 1909). The critique was recapitulated in two essays (Stolzmann 1914; 1919). Stolzmann engaged in a direct controversy with Böhm-Bawerk and an indirect controversy with Schumpeter's value and interest theory. Schumpeter formulated his value theory in his habilitation thesis (Schumpeter 1998) and in his now famous "Theory of Economic Development” (Schumpeter 2006). Schumpeter also mentioned Stolzmann in a separate essay about social value. He conceded that he had been somewhat influenced by Stolzmann (Schumpeter 1908). Stolzmann's value theory was criticized by one Marxist author, namely, Isaac Iljic Rubin. Rubin compared the 
value theory of Marx and Stolzmann and came to the conclusion that Stolzmann had used the wrong definition of society. Stolzmann represents an excessively teleological viewpoint of society and he separated social conditions too far from productive forces (Rubin 1928).

Stolzmann's value theory came from his Neo-Kantian theory of form and matter. Society or social awareness is represented by form and the relations of production are compatible with matter. For Stolzmann, form dominates matter. Society creates systems of values which are the basis for the law. The value of a good could be explained mainly by form. The socialists used the value of labour, the classical economists (Smith, Ricardo), the costs of production, and the neoclassical economists took marginal utility as the explanation factor for the value of a good, and as a consequence, for the price of a good. For Stolzmann, value itself cannot explain the economy as a whole, yet society explains value (Stolzmann 1925b, 39-40). One could simply say that Stolzmann used the top down approach and not the bottom up approach as the mentioned economic direction. For example, during the Middle Ages, value or price was not mainly determined from the market. It was mainly determined by the feudal lords. In capitalism, the market became the dominant place where the value of a good was determined. Therefore, Stolzmann concludes that the value is dependent on contemporary social and political circumstances. Another important factor for the value of a good is the distribution of wealth, which is again based on social and political circumstances. Stolzmann emphasized that the importance of the natural category should not be underestimated, because there are some natural restrictions (Stolzmann 1925b, 41-47). For example, the supply of commodities is scarce. To that extent, there is an influence on the value of a good (Stolzmann 1925b, 47).

\section{Critique of Stolzmann's Philosophy of Economics}

It is not clear why Stolzmann stopped pursuing the deductive approach in his fourth chapter of "Nature and Goals of the Philosophy of Economics.” The chapter about form and matter was not necessary from a deductive perspective as he went back to a subjective perspective. Given the Neoplatonic and Hermetic doctrine of macrocosm-mesocosm-microcosm relationship, it is logical that form dominates matter, because the soul is above matter in the neoplatonic hierarchy. Of course, neoplatonic philsophy is partly compatible with the Aristotelian hylomorphism doctrine. The eidos (form) is always dominant in comparison to the hyle (matter) (Aristoteles 1995, 146-7; Metaphysik, 1033b), but there is no added value. On the contrary, the concepts become even more complicated in the fourth chapter. The value theory could also be deviated from the macrocosm-mesocosm-microcosm scheme. There is no contradiction, because as Stolzmann assumed the value of a good is mainly determined by the mesocosm. The distribution of wealth and the legal relationship mainly determine the value and the price of a good. These two factors are the result of the several historical process in the society and in the economy.

Stolzmann correctly mentions the exception of the natural resources which are definitely scarce and also influence value. He could be considered as a typical Neo-Kantian philosopher and economist. Unfortunately, his ideas incorporated too many contradictionary aspects. Holzhey (1997, 226) defined Hermann Cohens philosophy correctly as Platonic or even Neoplatonic. Cohen was a representative of the Maribor Neo-Kantian school. The Platonic influence of Natorp has already been shown above. Hegel also influenced Neo-Kantian philosophy; especially Rickert’s work approaches Hegel (Krijnen 2007). Stolzmann was not completely aware that his deductive approach is not thinkable without Platon and Hegel and he mentioned about the subjective approach of Kant in the foreword of "Nature and Goals of the Philosophy of Economics" (Stolzmann 1925b, 6). 
For him, Kant represented the "right subjectivism" and the Austrian economists represented the "wrong subjectivism." Stolzmann had the problem that drawing on Kant was not suitable to fully refute the "wrong subjectivism." Therefore, he changed to a deductive approach where subjectivism disappeared. However, Stolzmann did not fully recognize that the credo "back to Kant" was not sustainable.

The chapters six and seven also contradict each other. Stolzmann talks about "Nature and Liberty" and "Nature and Liberty in the Economy." He again began with the Kantian subject to explain the terms nature and liberty and the originally deductive aims disappeared. The conclusion is that the deductive approach was used inconsequently and is not compatible with Kantian philosophy.

\section{Conclusions}

In his essay "Nature and Goals of a Philosophy of Economics," Stolzmann tried to change his methodological position. He wanted to use a deductive approach to explain his socially organic philosophy. At the beginning, the project was plausible and successful, but Stolzmann was not consistent in using this method. This led to confusion and contradictions. He made a similar mistake to other Neo-Kantian philosophers, such as Paul Natorp. They wanted to synthesize subjective Kantian philosophy with that of Hegel and Platon.

The macrocosm-mesocosm-microcosm analogy was a sound basis for the explanation of the value of a good. The socially organic theory and philosophy of Stolzmann would have had a fundamental background. However, Stolzmann was not consistent enough. This may have been a reason why there was not any detailed research on Stolzmann's philosophy of economics.

\section{Notes}

1. The essay was released in 1914. E. v. Böhm-Bawerk. (1914). "Zeitschrift für Volkswirtschaft, Sozialpolitik und Verwaltung” Band 23. 205-71.

2. The book of Stolzmann was edited in 1923. In this essay, the second edition is used.

3. Schumpeter released the book in 1912.

4. It was not unusual at the 19th and at the beginning of the 20th century that economists considered the economy as a social organism. For example, for Jean Baptiste Say the society was a social organism and he used the term "economiesociale" (Say 1966, 5-6). For Swedberg, Say was the first representative of a social economy (Swedberg 1995, 529).

\section{Works Cited}

Aristoteles. Philosophische Schriften in sechs Bänden. Band 5. Metaphysik (Philosophical Works in Six Volumes. Volume 5. Metaphysics). Eds. Bonitz Hermann and Seidl Horst. Hamburg: Felix Meiner Verlag, 2010.

Böhm-Bawerk, Eugen von. Kleinere Abhandlungen über Kapital und Zins. Gesammelte Schriften. 1. Band (Treatises about Capital and Interest. Collected Works. Volume 1). Wien: Hölder-Pichler Dempsky AG, 1924.

Diehl, Karl. Die sozialrechtliche Richtung der Nationalökonomie (The Social Law Movement in Economics). Jena: Verlag von Gustav Fischer, 1941.

Ebeling, Florian. Das Geheimnis des Hermes Trismegistos. Die Geschichte des Hermetismus (The Secret of Hermes Trismegistus. History of Hermetism). First edition. München: Verlag C. H. Beck, 2005.

Esser, Hans A. Macht oder ökonomisches Gesetz. Zur wert- und verteilungstheoretischen Kontroverse zwischen Rudolf Stolzmann und Eugen v. Böhm-Bawerk (Power or Economic Law. The Controversy about Value Theory and the Theory of Distribution of Rudolf Stolzmann and Eugen v. Böhm-Bawerk). Institut for Economic Policy University of Köln, 1971. 
Holzhey, Helmut. "Platonim Neukantianismus (Plato in Neo-Kantian Philosophy).” Ed. Kobusch, Theo/Mojsisch, Burkhard. Platon in der abendländischen Geistesgeschichte. Neue Forschungen zum Platonismus (Plato in the History of Western Ideas. New Investigations in Platonism) (S. 226-40). Darmstadt: Wissenschaftliche Buchgesellschaft, 1997. 226-40.

Kant, Immanuel. Kritik der reinen Vernunft. Kants sämtliche Werke (Critique of Pure Reason. The Complete Works of Kant). 9th edition. Ed. Valentiner Theodor. Leipzig: Verlag der Dürrschen Buchhandlung, 1906.

Krijnen, Christian. "Hegel und der Neukantianismus. Eine systemphilosophische Konfrontation (Hegel and Neo-Kantianisms. A System Philosophical Controversy).” Ed. Heidemann, Dietmar/Krijnen, Christian. Hegel und die Geschichte der Philosophie (Hegel and the History of Philosophy). Darmstadt: Wissenschaftliche Buchgesellschaft, 2007. 240-59.

Lange, Friedrich Albert. Die Arbeiterfrage (About the Condition of Workers). Leipzig: Alfred Kröner Verlag, 1910.

Lechner, Gerhard. “Stolzmann’s Influences on Schumpeter’s Interest Theory.” Canadian International Journal of Social Sciences and Education 9 (2016): 49-61.

Natorp, Paul. Platos Ideenlehre: Eine Einführung in den Idealismus (Plato's Concept of Ideas: An Introduction to Idealism). Leipzig: Dürr Verlag, 1903.

Pascher, Manfred. Einführung in den Neukantianismus. Kontext—Grundpositionen—praktische Philosophie (An Introduction to Neo-Kantianism. Context-Home Position-Practical Philosophy). München: Wilhelm Fink Verlag, 1997.

Rieter, Heinz. "Historische Schulen (Historical Schools).” Ed. Ottmar Issing. Geschichte der Nationalökonomie (History of Economics). 4th edition. München: Verlag Franz Vahlen. 2014. 131-69.

Rickert, Heinrich. Der Gegenstand der Erkenntnis. Einführung in die Transzendentalphilosophie (The Objects of Knowledge. Introduction into Transcendental Philosophy). Tübingen: Mohr, 1928.

---. Die Grenzen der naturwissenschaftlichen Begriffsbildung. Eine logische Einleitung in die historischen Wissenschaften (The Limits of the Conceptualization in Natural Sciences. A Logical Introduction into Historical Sciences). 5th edition. Tübingen: J. C. B. Mohr, 1929.

Rubin, Isaak Iljic. "Stolzmann als Marxkritiker (Stolzmann as a Critique of Marx).” Marx-Engels Archiv. Zeitschrift des Marx-Engels-Instituts in Moskau (Journal of Marx-Engels Institute Moscow). Band 1. Frankfurt/M. 1928. $370-86$. $<$ https://www.marxists.org/deutsch/archiv/rubin/1928/xx/stolzmann.htm>.

Say, Jean Baptiste. Cours complete d'economiepolitique. Troisieme edition, reimpression de l'edition 1852 (A Treatise on Political Economy. 3rd edition. Reprint 1852). Osnabrück: Proff \& Co. KG, 1966.

Schöpfer, Gerald. “Umbrüche und Kontinuitäten. Politische Wechsellagen und Karriereverläufe in Österreich nach 1918-eine unvollständige Gedankenskizze (Upheavals and Consistencies. Political Vicissitudes and Careerpathsin Austria after 1918-An Incomplete Conceptual Sketch).” Eds. Karner Stephan and Mikoletzky Lorenz. Österreich. 90 Jahre Republik (Austria. 90 Years as a Republic). Innsbruck: Studienverlag, 2008. 331-43.

Schumpeter, Joseph Alois. “On the Concept of Social Value.” Quarterly Journal of Economics 23 (1908): 213-32.

---. Das Wesen und der Hauptinhalt der theoretischen Nationalökonomie (The Nature and Main Content of Theoretical Economics). 3rd edition. Berlin: Duncker und Humblot, 1998 [1908].

---. Die Theorie der wirtschaftlichen Entwicklung (The Theory of Economic Development). Berlin: Verlag Duncker \& Humblot, 2006 [1912].

Stavenhagen, Gerhard. Geschichte der Wirtschaftstheorie (History of Economic Theory). 3rd edition. Göttingen: Vandenhoeck \& Ruprecht, 1964.

Stolzmann, Rudolf. Die soziale Kategorie in der Volkswirtschaft (The Social Category in Economics). Berlin: Verlag Puttkammer \& Mühlbrecht, 1896.

---. Der Zweck in der Volkswirtschaft. Die Volkswirtschaft als sozial-ethisches Zweckgebilde (The Purpose in the Economy. The Economy as a Social-Ethical Purpose). Berlin: Verlag Puttkammer \& Mühlbrecht, 1909.

---. "Die Kritik des Subjektivismus an der Hand der sozialorganischen Methode (The Critique of Subjectivism on the Basis of the Social Organic Method).” Jahrbücher für Nationalökonomie und Statistik/Journal of Economics and Statistics, Dritte Folge, Vol. 48 (103), No. 2 (1914): 145-92.

---. “Das Reinökonomische am System der Volkswirtschaft (The Pure-Economics in the System of Economics).” Jahrbücher für Nationalökonomie und Statistik/Journal of Economics and Statistics, Dritte Folge. Band 57.112 (1919): 385-432.

---. Grundzüge einer Philosophie der Volkswirtschaft. Versuch einer Volkswirtschaft auf philosophischem Grunde (Basics of a Philosophy of Economics. The Economy from a Philosophical Position). 2nd edition. Jena: Verlag von Gustav Fischer, 1925a. 
Stolzmann, Rudolf. Wesen und Ziele der Wirtschaftsphilosophie (Nature and Goals of a Philosophy of Economics). Berlin: Verlag von Gustav Fischer, 1925b.

---. “Die Ganzheitslehre Ottmar Spanns (The Holism of Othmar Spann).” Jahrbücher für Nationalökonomie und Statistik/Journal of Economics and Statistics. Dritte Folge. Vol. 72 (127). No. 6 (1927): 881-918.

Swedberg, Richard. “Schumpeter's Vision of Socioeconomics.” Journal of Socio-Economics 24. 4 (1995): 525-44.

Yates, Frances Amelia. Giordano Bruno and the hermetic tradition. London: Routledge \& Keganpress, 1964.

Zeidler, Walter. "Versuche einer kritischen Aneignung der Dialektik bei Hönigwald und Bauch (An Attempt of a Critiqual Appropriation of Dialectics at Hönigwald and Bauch).” Eds. Pötzold, D. and Krijnen, C. Der Neukantianismus und das Erbe des deutschen Idealismus: die philosophische Methode (Neo-Kantianism and the Heritage of German Idealism: The Philosophical Method). 2002. 181-94. 